\title{
Hindi Language
}

National Cancer Institute

\section{Source}

National Cancer Institute. Hindi Language. NCI Thesaurus. Code C153948.

A standardised and Sanskritised reg ister of the Hindustani language. 